Artigos diversos 



\title{
Do humanismo ético aos direitos humanos
}

\section{- Del humanismo ético a los derechos humanos}

- From ethical humanism to human rights

\section{Alexandre Silva Guerreiro'}

\begin{abstract}
Resumo: O conceito de humanismo passou por transformações ao longo do tempo. Desde a Grécia Antiga até a contemporaneidade, formou-se um caleidoscópio humanista que abarca significados diversos e, até mesmo, antagônicos. Este artigo propõe uma investigação sobre o humanismo, tendo como objetivo a formulação do humanismo ético para, em seguida, conectá-lo aos direitos humanos. Para isso, considera-se a contribuição de Emmanuel Lévinas $(1993,2008)$ no que concerne à responsabilidade pelo Outro, bem como a formulação da ética como relacional de acordo com Olinto Pegoraro (2005). A partir disso, buscamos aproximar humanismo ético e direitos humanos. No entanto, é preciso entender os direitos humanos dentro de uma perspectiva polissêmica que também marca o humanismo, trazendo para essa relação a noção de direitos humanos contra-hegemônicos, conforme proposta por Boaventura de Sousa Santos (2014). Humanismo ético e direitos humanos encontram-se no desejo de transformação da realidade a partir da reflexão e da ação. Assim, concluímos que os direitos humanos, em sua translação contra-hegemônica, com sua pulsão pela positivação de direitos e pela valorização das diferenças e da diversidade, são atravessados por um humanismo ético que está profundamente conectado com o desejo de mudança social e de responsabilidade pelo Outro, numa perspectiva levinaseana.
\end{abstract}

Palavras-chave: Humanismo. Ética. Lévinas. Direitos Humanos.

1 Doutor em Comunicação pela UFF, com pós-doutorado em Educação pela UFRJ. É Professor de História e Filosofia na Secretaria de Estado de Educação do Rio de Janeiro. alexandreguerreiro@hotmail.com 
Resumen: El concepto de humanismo ha experimentado transformaciones a lo largo del tiempo. Desde la Antigua Grecia hasta la época contemporánea, se formó un caleidoscopio humanista que engloba significados diferentes o incluso antagónicos. Este estudio propone una investigación sobre el humanismo con el objetivo de formular el humanismo ético y luego conectarlo con los derechos humanos. Para eso, consideramos la contribución de Emmanuel Lévinas $(1993,2008)$ con respecto a la responsabilidad para con el Otro, así como la formulación de la ética como relacional según Olinto Pegoraro (2005). A partir de esto, buscamos aunar el humanismo ético y los derechos humanos. Sin embargo, es necesario entender los derechos humanos desde una perspectiva polisémica que también marca el humanismo, trayendo a esta relación la noción de derechos humanos contrahegemónicos, como propone Boaventura de Sousa Santos (2014). El humanismo ético y los derechos humanos se encuentran en el deseo de transformar la realidad a través de la reflexión y la acción. Así, concluimos que los derechos humanos, en su traducción contrahegemónica, con su afán por la positivación de los derechos y por valorar las diferencias y la diversidad, están atravesados por un humanismo ético que está profundamente conectado con el deseo de cambio social y con la responsabilidad por el Otro, en un perspectiva levinaseana.

Palabras clave: Humanismo. Ética. Lévinas. Derechos humanos.

Abstract: The concept of humanism has undergone transformations over time. From ancient Greece to contemporary times, a humanistic kaleidoscope was formed that encompasses different and even antagonistic meanings. This article proposes an investigation on humanism, aiming at the formulation of ethical humanism and then connecting it with human rights. For this, we consider Emmanuel Lévinas contributions $(1993,2008)$ regarding responsibility for the Other, as well as the notion of ethics as relational according to Olinto Pegoraro (2005). Also, we seek to bring together ethical humanism and human rights. However, it is necessary to understand human rights within a polysemic perspective that also marks humanism, bringing to this relation the notion of counter-hegemonic human rights, as proposed by Boaventura de Sousa Santos (2014). Ethical humanism and human rights come together with the desire to transform reality through reflection and action. Thus, we conclude that human rights, in their counter-hegemonic translation with their drive for positivation of rights and differences and diversity valorization are crossed by an ethical humanism that is deeply connected with the desire for social change and responsibility for the Other, in a Levinasean perspective.

Keywords: Humanism. Ethic. Lévinas. Human Rights. 


\section{Introdução}

Os direitos humanos guardam com o humanismo uma relação, até certo ponto, silenciosa e inexplorada. Ambos encontram defensores apaixonados e acusadores radicais; mas um olhar atento revela que, em geral, os atores que ocupam tais extremos se referem a concepções bastante diversas de cada um desses conceitos. A questão do discurso hegemônico versus o discurso contra-hegemônico dos direitos humanos (SANTOS; MARTINS, 2019) é pauta obrigatória para o aprofundamento do termo atualmente. Do mesmo modo, o humanismo assume significados radicalmente contrários que podem ser revelados numa investigação mais atenta do termo.

Este trabalho tem como objetivo aprofundar uma discussão sobre o humanismo em suas diversas acepções, atrelando um entendimento desse conceito à ética para, por fim, apontá-lo como elementar numa concepção contra-hegemônica dos direitos humanos. Por meio de pesquisa bibliográfica, assumimos uma perspectiva hermenêutico-interpretativa para abordar o conceito de humanismo por entre os autores convocados ao longo de nossa reflexão. Nossa intenção, longe de esgotar a discussão, é dar ênfase ao caráter polissêmico do termo, ponderando em que medida o humanismo, adjunto ao conceito de ética, funciona como parâmetro para compreendermos os direitos humanos na contemporaneidade, dentro de uma angulação contra-hegemônica.

Tema dos mais controversos, o humanismo oscila entre defensores e detratores radicais, a ponto de ter sido condenado a certo ostracismo, talvez por ser evocado em discursos distintos, até mesmo antagônicos. Algumas obras se dedicaram a elencar humanismos e anti-humanismos, e inúmeros autores mergulham, hoje, na seara do pós-humanismo. Para construir a polissemia do termo, montaremos uma espécie de caleidoscópio humanista, do qual extrairemos a ideia de responsabilidade pelo Outro (LÉVINAS, 1993, 2008) como central para pensarmos os direitos humanos. Já a ética, que nos remete com mais precisão do que o humanismo à antiguidade clássica, é um termo que passou por certa evolução e constitui-se como importante chave de leitura do humanismo, sobretudo na formulação da ética como necessariamente relacional (PEGORARO, 2005). Com efeito, ética e humanismo são conceitos antigos e correlatos que merecem atenção quando pensamos na contemporaneidade. Nosso objetivo é refletir sobre o que consideramos como falsos humanismos e iluminar o humanismo ético como fundamento dos direitos humanos.

Se sustentamos que se trata de um termo controverso é porque não há nenhum consenso sobre o que seja o humanismo. As definições primeiras de humanismo estão na contramão de alguns humanismos que elencaremos, e mesmo do que defendemos. Não havendo, portanto, um mínimo denomi- 
nador comum que possa alinhavar todas as diversas vertentes, o termo chega a ser esvaziado de sentido, perdendo sua aplicabilidade, salvo se buscarmos uma nova definição que nos permita utilizá-lo.

Seria possível, a partir de um aclaramento dos diversos humanismos, assumir os direitos humanos como sendo gerados por um pensamento que encontre suas raízes num humanismo ético? Qual a importância de relacionarmos humanismo ético e direitos humanos, considerando que são termos controversos e polissêmicos, e em que medida essa junção contribui para iluminar uma concepção de ambos que reafirme uma união entre teoria e prática? O encontro entre direitos humanos e humanismo ético nos permite imaginar, através dessas questões, uma maneira de estar no mundo em que a responsabilidade pelo Outro seja entendida como central.

\section{0 caleidoscópio humanista}

As definições mais imediatas do humanismo nos remetem, basicamente, a dois significados. O primeiro se refere ao período do Renascimento Cultural, com início na Itália do século XIV, espalhando-se pela Europa no século seguinte. Trata-se de um movimento intelectual de resgate dos valores greco-romanos e que teve como marca o antropocentrismo. $O$ segundo é uma filosofia que não está atrelada a um momento histórico específico ou a uma determinada localidade. Nesse sentido, o humanismo seria qualquer doutrina filosófica que valoriza o ser humano reconhecendo-o como central no mundo, e que reflete sobre as possibilidades de transformação da realidade social e natural que o cerca.

Em comum, esses dois significados possíveis e rasos para o humanismo amparam-se no antropocentrismo, que marca o Renascimento Cultural em oposição ao teocentrismo medieval, mas também perpassa qualquer filosofia que pense a centralidade do ser humano no mundo. Mas cabe a reflexão: qual a origem desse pensamento, antes mesmo de ser um conceito?

Podemos encontrar uma resposta possível na Grécia Antiga, na figura do filósofo Protágoras, sofista que viveu entre 490 e 415 a.C, e formulou o pensamento do homem como central no universo. Sua célebre frase resume a ideia do homem como ser central, em torno do qual tudo gira, o que é a própria essência do antropocentrismo que marcará o Renascimento dois mil anos depois: "O homem é a medida de todas as coisas, das que são como são e das que não são como não são" (apud MARCONDES, 2002, p. 43). Acusado de ateísmo e tendo livros queimados em praça pública, Protágoras abandonou Atenas e isolou-se na Sicília até a sua morte, o que mostra que tal pensamento, central para o conceito de humanismo, é desestabilizador desde sempre. 
Nesse sentido, podemos falar, segundo Carla Brandalise (2004), em uma cultura humanista que atravessa a história, tendo início na antiguidade com Protágoras. Para a autora, humanismo é:

[...] a tradição cultural que coloca o homem no centro das preocupações filosóficas. Tal manifestação vinha sendo intermitente na história europeia, mas jamais atingira a grandiosidade da civilização renascentista italiana. De fato, a cultura humanística renasce na Itália. (BRANDALISE, 2004, p. 17-18)

Ainda que a palavra humanismo só tenha passado a vigorar na virada do século XVIII, em referência ao movimento italiano do século XIV, a ideia que gira em torno do termo existia, portanto, desde a antiguidade, atingindo seu auge no início da Idade Moderna. Contudo, ao evocar o humanismo, muitos autores misturam as duas significações supracitadas, fazendo convergir o humanismo como doutrina filosófica e as características do humanismo renascentista. "O humanismo é indissociável, portanto, à erudição" (BRANDALISE, 2004, p.18). Longe de ser um consenso, essa ideia é mesmo falaciosa e indica para um denominador comum inexistente, concretizando nossa indicação de que algumas vertentes do humanismo chegam a ser antagônicas. O desafio, aqui, é indicar os domínios nos quais cada vertente humanista circula.

A questão da erudição perpassa várias definições do humanismo. Lúcia Santaella (2010) salienta que, "como entendido historicamente, o humanismo pertence sempre a um estudo da humanidade que remete à antiguidade e que sempre se converte em se reviver os gregos." (p. 105). O que aponta para a erudição, para o conhecimento, afasta e hierarquiza saberes e autores que trabalham dentro de uma perspectiva humanista sem transformar o saber em moeda, sem considerar que o humanismo se caracterize pela formação ou erudição de seus seguidores. Santaella considera os diversos humanismos existentes em oposição à ideia de erudição.

Entretanto, se entendemos o humanismo em geral como o empenho para que o homem tenha a liberdade de assumir sua liberdade e nisso encontra a sua dignidade, então, dependendo da maneira como se entende liberdade e dignidade, o humanismo, em cada caso, diferirá. Assim, o humanismo de Marx não é o mesmo humanismo de Sartre, assim como estes não se confundem com o humanismo cristão. (SANTAELLA, 2010, p.106)

Mesmo assim, é comum a insistência na civilização grega como berço do humanismo. Pedro Dalle Nogare (1981) aponta os sofistas como sendo os primeiros humanistas, salientando que"o grande mérito deles é de ter chamado com insistência a atenção dos sábios para os problemas humanos." (p. 30). Porém, após discorrer sobre as contribuições de Platão, como o filósofo que inaugura uma especulação sistemática sobre o homem, e Aristóteles, cuja 
proposição de alma e corpo indissociável alimentará as pesquisas medievais, sobretudo a de São Tomás de Aquino, o autor chama a atenção para o fato de que a questão humana na Grécia Antiga se restringia a uma parcela mínima aristocrática, alijando dessa discussão a maior parte da população.

[...] pode-se dizer que o homem, na Antiguidade grega, coloca-se em posição privilegiada, sendo particularmente realçados os valores de beleza, força, harmonia, heroísmo, gênio, etc. Mas em geral isso vale só para uma minoria aristocrática, enquanto a massa (escravos, mulheres, etc.) não tem significado. Falta aos Antigos o conceito de pessoa e continua para todos sem solução o problema da origem do sentido da existência humana. (NOGARE, 1981, p. 38-39)

Se tomamos a asserção de Protágoras como um marco no pensamento grego sobre o homem, não o fazemos no sentido de excluir a presença do humanismo em sentido amplo, em inúmeras outras civilizações. Ao dissociarmos o humanismo da questão da erudição, o conceito ganha outra conotação, ficando mesmo em campo oposto à ideia de conhecimento ou de saber.

Ainda que o propagado humanismo cristão exponha as qualidades de uma doutrina religiosa, qualidades estas que podem ser encontradas com variações em inúmeras outras religiões, o catolicismo atuava para manter o controle do conhecimento, impedindo que livros considerados perigosos circulassem. Essa lista, na verdade, foi utilizada já no século XVI e perdurou até o século XX. A data de extinção é 1966 e foi feita pelo Papa Paulo VI. Naturalmente, o vigor do Index Librorum Prohibitorum não era tão grande nos últimos séculos, mas a ideia de silenciar aqueles que pensavam de maneira diferente não estava apenas no ato de tirar de circulação os livros de certos autores, mas também de prender, julgar e condenar à morte pessoas comuns acusadas das mais variadas heresias, através da Inquisição, que perdurou até o século XIX.

Talvez as datas em que tais práticas foram extintas ajudem a combater a ideia de que o medievo foi o período em que a Igreja Católica lançava mão de tais ações. Na verdade, a partir do Renascimento tentou-se, por oposição, indicar a Idade Média como uma época de trevas, mas existem inúmeras continuidades, tanto positivas, vide o florescimento das universidades, quanto negativas, como o incremento da violência católica como reação ao surgimento das igrejas protestantes. Seja como for, fica claro que a reivindicação de um humanismo cristão está baseada no absoluto descolamento entre teoria e prática, o que nos parece elemento fundamental para pensarmos o humanismo que defendemos aqui. A apropriação da noção de humanismo pela Igreja Católica se faz, naturalmente, na contramão do que pensava Protágoras.

A convergência de humanismo e cristianismo é das mais controversas. Constantemente, acusa-se o ateísmo como um risco e defende-se o humanismo cristão em nome do amor. Em Humanismos e Anti-humanismos, após 
discorrer sobre o humanismo na antiguidade e no medievo, e de abordar, de forma quase acusatória, o humanismo marxista ou existencialista, Nogare evoca a Bíblia em defesa do humanismo. "Devem ser interpretadas corretamente as palavras da Bíblia, que parecem estar na base - ou pelo menos terem sido um dos fatores principais - do espetacular desenvolvimento científico e tecnológico do mundo ocidental." (1981, p.235). Mais adiante, Nogare ataca frontalmente o ateísmo, usando como munição o próprio humanismo.

Pareceu e parece a muitos que o problema religioso coloca-se nos
termos de uma alternativa ou de uma opção entre Deus e o homem.
Quem escolher a Deus, "ipso facto" deverá renunciar à completa reali-
zação de si mesmo como homem; quem escolher o homem, não po-
derá aceitar a interferência de um Criador, Senhor, Juiz de sua persona-
lidade e atividade. O ateísmo contemporâneo - repetimos - é o reverso
da medalha de um humanismo mal-entendido. (NOGARE, 1981, p. 268)

A obra Filosofia e Humanismo, de Jessy Santos, é sintomática da defesa de um humanismo cristão em detrimento dos demais e, sobretudo, descolado da prática. "O humanismo tem sido, no decurso da história da humanidade, a meta anunciada por profetas e sábios. Porém, nos tempos atuais adquiriu conotação pragmática." (1981, p.17). O autor condena abertamente o humanismo sartreano e marxista, precipitando na metafísica a possibilidade de realização plena do homem.

Infelizmente os homens se distanciam cada vez mais da condição ideal. As aspirações humanas estão voltadas para a satisfação dos apetites sensuais, dando as costas para a fonte da espiritualidade que é a mística do transcendental. Essa aspiração do transcendente, essa aspiração da sobrevivência da consciência, é que pode dar ao homem atual a noção exata dos valores espirituais; e estes são os que qualificam e dignificam a pessoa humana. A ciência e a máquina absorvem o homem contemporâneo. A plasticidade espiritual está, talvez, momentaneamente congelada. O homem é apenas um complexo somático sacudido pelas emoções sensoriais. (SANTOS, 1981, p. 150)

Sendo assim, parece-nos que o humanismo cristão antepõe-se ao humanismo marxista na medida em que retira do homem a possibilidade de realizar-se a si próprio. De fato, Marx parte da emancipação do homem frente ao sistema econômico, à alienação e ao capitalismo. "A própria meta de Marx é libertar o homem da pressão das necessidades econômicas, de modo a poder ser completamente humano." (FROMM, 1983, p.16). Contudo, entre essas duas concepções radicalmente opostas, vale destacar outras vertentes humanistas. 
É o caso do humanismo positivista ${ }^{2}$ ou do humanismo logosófico ${ }^{3}$. Em ambos os casos, há uma recusa da metafísica e da teologia e a inscrição no homem das possibilidades de seu futuro, distanciando o conceito de uma perspectiva religiosa. O humanismo positivista, ao propor a Religião da Humanidade ${ }^{4}$, exclui desta a metafísica e a teologia, criando uma religião do e para o homem.

Coloca-se, aqui, a questão dos extremos no que se refere ao conceito de humanismo. Se iniciamos este artigo ponderando sobre as definições de humanismo, sendo uma mais próxima de erudição e outra apontada como doutrina filosófica, precisamos entender que neste segundo sentido não há consenso, sendo mesmo impossível evocar o conceito e se fazer entender plenamente. A distância entre amor, caridade, de um lado, e luta por justiça social de outro, dá o tom da seara que se abre diante da noção de humanismo, e se nos colocamos o desafio de adotar esse conceito é por pensarmos que vale uma reflexão sobre suas origens e seus sentidos.

O que podemos perceber nesse caleidoscópio humanista é que, em nenhum momento, as definições ocupam o mesmo lado. Longe da máxima do homem como medida de todas as coisas, o humanismo segue vertentes tão díspares quanto contraditórias, e torna-se necessário pensarmos no sentido mais elementar do humanismo em que acreditamos, excluindo de nosso horizonte aqueles que se tornam até mesmo nocivos. O que defendemos é que não há humanismo descolado da prática, razão pela qual recusamos um humanismo baseado na erudição. Com isso, questionamos até mesmo a formulação de um humanismo cristão, haja vista a distância entre o ideário cristão, ou ainda de outras religiões, e o que as diversas igrejas, ou seus seguidores, praticam. Nesse sentido, nos aproximamos do humanismo existencialista, dentre os quais é possível se encontrar um denominador comum, para avançarmos até a noção de um humanismo ético.

No livro O Existencialismo é um humanismo, Jean-Paul Sartre deixa claro

2 Ao pressupor a superação da teologia e da metafísica e ancorando o conhecimento na experiência concreta, Augusto Comte (1798-1857) deu um importante passo para a formulação de um humanismo ancorado numa teoria social que assume a centralidade do homem. Em que se pesem as críticas ao positivismo, como a aplicação das ciências exatas ao comportamento humano, é importante considerar que os positivistas pregam a superação das superstições e crenças como condição para o progresso da humanidade.

3 O argentino Gonzalez Pecotche (1901-1963) foi um pensador humanista que criou a Logosofia, uma escola fundada em 1930, em Córdoba, que tinha por objetivo a evolução consciente do homem. O conhecimento de si mesmo passaria, necessariamente, pela ideia de ajudar o semelhante. A Logosofia possui sede em diversos países, sempre ancorada no ensino curricular e na formação do aluno visando o autoconhecimento e o preparo responsável para atuar no mundo como um servidor da humanidade.

4 A Religião da Humanidade, criada por Auguste Comte na obra Sistema de política positiva (1854), busca instituir a Humanidade como Ser Supremo. Considerando que as religiões existentes até então jamais lograram a construção de um espírito positivo, Comte vê a necessidade de criação dessa nova religião, voltada para o homem. $\mathrm{O}$ altruísmo definiria, segundo Comte, o ideal da nova religião, que tem como regime viver para outrem. A Religião da Humanidade segue o lema: Amor por princípio, ordem por base, o progresso por fim. 
um conceito de humanismo completamente distante do ideário cristão. Partindo do pressuposto da inexistência de Deus e da ideia, alicerce do existencialismo, de que a existência precede a essência, Sartre $(2014$, p. 44) afirma que

\begin{abstract}
O existencialismo não é outra coisa senão um esforço para extrair todas as consequências de um posicionamento ateu coerente. De forma alguma ele pretende mergulhar o homem no desespero. Mas se, como os cristãos, chamarmos de desespero toda a atitude de descrença, o existencialismo, então, parte do desespero original. [...] O homem precisa encontrar-se ele próprio e convencer-se de que nada poderá salvá-lo de si mesmo, mesmo que houvesse uma prova incontestável da existência de Deus. Neste sentido, o existencialismo é um otimismo, uma doutrina de ação, e apenas por má-fé é que, confundindo seu próprio desespero com o nosso, os cristãos podem nos chamar de desesperançados.
\end{abstract}

Sartre aponta, assim, para a definição do conceito de humanismo que coloca nas mãos do homem a construção de seu próprio destino. Em relação ao humanismo marxista, a concepção de Sartre se distancia pelo caráter individualista do existencialismo, mas ambas comungam a centralidade do homem de uma maneira concreta, voltada para a realização do homem no mundo, aqui e agora, e desconsiderando uma discussão metafísica. O humanismo marxista e existencialista é voltado para a prática, para a transformação do mundo, fazendo sumir no horizonte uma perspectiva religiosa do conceito.

Assim, não há natureza humana, pois não há um Deus para concebê-la. O homem é, não apenas como é concebido, mas como ele se quer, e como se concebe a partir da existência, como se quer a partir desse elã de existir, o homem nada é além do que ele se faz. Esse é o primeiro princípio do existencialismo. (SARTRE, 2014, p. 19)

É interessante notar que, ao final do livro, originário de uma conferência realizada em 1945, em Paris, no Clube Maintenant, Sartre responde a algumas perguntas, e um de seus interlocutores, o sociólogo Pierre Naville, ao questioná-lo sobre o humanismo, aponta para o caleidoscópio que buscamos desenhar aqui, defendendo, porém, uma posição diferente da nossa.

Humanismo, hoje, infelizmente, é um termo que serve para designar as correntes filosóficas, não apenas em dois sentidos, mas em três, quatro, cinco, seis. Todo mundo é humanista agora, mesmo alguns marxistas que se descobrem racionalistas clássicos são humanistas em um sentido insípido, derivado das ideias liberais do século passado, de um liberalismo refratado ao longo de toda a crise atual. Se os marxistas podem pretender-se humanistas, as diferentes religiões, os cristãos, os hindus e muitos outros também pretendem ser acima de tudo humanistas, assim como o existencialismo e, de maneira geral, todas as filosofias. (NAVILLE, 2014, p. 53)

Se não decantamos os sentidos de humanismo, do cristianismo às 
concepções do humanismo sartreano ou marxista, contribuímos para a indefinição do que seja o conceito que queremos clarificar. Como o próprio Sartre aponta ao referir-se aos cristãos, há algo de má-fé na acusação do humanismo existencialista, ou mesmo do humanismo marxista.

De certa forma, os dois significados básicos de humanismo que vimos também apontam para, de um lado, a erudição, associada à racionalidade humana, de outro, nossa capacidade de sensibilização pelo outro, e como veremos em Lévinas, nossa responsabilidade pelo Outro, que está no cerne de um humanismo ético.

\section{Do humanismo ético aos direitos humanos}

A Grécia Antiga é considerada o berço da Ética, mas podemos conceber, também, que a Ética como investigação da conduta humana acompanha o homem que vive em sociedade. $O$ ethos, de certa forma, busca fundamentar as ações morais e, nesse sentido, podemos apontar a Ética como a ciência que estuda o comportamento humano. Ética enquanto filosofia apoia-se, sobretudo, no desenvolvimento de sistemas éticos por diversos pensadores, de Aristóteles a Kant, de Spinoza a Schopenhauer, mas isso não impede a existência de um movimento de reflexão sobre o comportamento humano, independentemente de sua erudição.

Frequentemente, é atribuído a Aristóteles o desenvolvimento de um primeiro sistema ético. Com efeito, Platão e Aristóteles foram pensadores pioneiros no que diz respeito a trabalhos mais cuidadosos sobre a Ética. Porém, isso se deu de maneira diversa: aquele repercute no conceito de Ética sua visão dualista do mundo, marcada por uma abordagem idealista e racionalista; este, em contrapartida, apresenta uma abordagem da Ética fundamentada no empirismo, abandonando o viés idealista formulado por seu mestre. Em Ética a Nicômaco (1991), Aristóteles discorre sobre a virtude, considerando que esta é adquirida. A virtude estaria associada ao saber e à cultura, o que contribui para um pensamento que considera a virtude como algo a ser ensinado. $\mathrm{O}$ sistema ético criado por Aristóteles semeou o terreno no qual se desenvolveu uma concepção de Ética voltada para o ser humano e para o mundo empírico, mas também atrelada ao conhecimento e à erudição.

Para além de Aristóteles, vale pensarmos na ética dissociada da erudição. Em Introdução à ética contemporânea, Olinto Pegoraro (2005, p. 26) indica que

A ética não é inventada por um sábio ou um santo; ela se origina na relação viva entre um eu e um tu ou entre duas pessoas. Portanto, a ética é relacional. Surge do convívio das pessoas e das comunidades. A reciprocidade interpessoal estabelece a eticidade de nossos comportamentos e ações. 
Nesse sentido, o filósofo Epicuro merece ser aqui considerado. Sua filosofia aproxima-se intensamente de uma perspectiva laica, não-metafísica, pragmática. Uma das grandes críticas de Epicuro ao pensamento de seu tempo era o grau de superstição das pessoas, ao que muitos filósofos não estão imunes. Sendo assim, para Epicuro, os deuses existem, mas não se ocupam de nós, e o que fazemos não tem repercussão além da morte. A metafísica, portanto, não é uma questão central. De acordo com o atomismo, que Epicuro herda de Demócrito e aperfeiçoa, somos criados pelo acaso a partir do encontro fortuito de átomos, e com a morte, esses átomos se separam para formar outras possibilidades de existência.

O que subjaz na filosofia epicurista é uma valorização do comportamento humano, uma vez que o ser humano não deve fazer o bem por temer o sobrenatural ou a morte, por corresponder ao desejo dos deuses, mas por ter responsabilidade em relação ao Outro. A ética em Epicuro é relacional, e erroneamente atrelada ao hedonismo, pois o prazer de que fala o filósofo passa pela valorização da amizade. Na verdade, a ideia é que ao fazer o bem ao outro, fazemos o bem a nós mesmos.

A dupla natureza da proposta epicurista - aliar razão iluminadora e amor à humanidade, lúcida compreensão dos fenômenos naturais e procura da felicidade terrena, ciência e ética - justifica, em parte, a aparência de seita, o caráter de confraria assumido por essa corrente filosófica. Trata-se, porém, de confraria laica, centrada na valorização do humano, não na transcendência do divino; confraria de amigos da verdade alcançada pelos sentidos e pela razão; confraria que procura a salvação, sim, mas por meio do conhecimento, não da crença, por meio da filosofia enquanto compreensão clara e comprovável, não da adesão ao mistério, ao intelectual e empiricamente insondável. (PESSANHA, 2002, p. 59)

Sendo assim, ao afastar a filosofia da metafísica, ao trazê-la para o mundo dos homens, ao dotá-la de uma funcionalidade que ajude os seres humanos a se relacionarem, o que está colocado pelo epicurismo é o pensamento como transformador das coisas e do mundo. A negação da religião explica o porquê do epicurismo ter sido severamente criticado ou, até mesmo, reduzido ao hedonismo. A verdade é que tanto a filosofia de Platão quanto a de Aristóteles foram, de certa forma, cooptadas pelo cristianismo, mas isso não poderia acontecer com o epicurismo, voltado para as coisas terrenas, para os homens e declaradamente laica. Epicuro estabelecia, então, as bases para um humanismo radical e para uma ética da responsabilidade.

Não resta dúvida de que a Ética, desde seus primórdios, originou concepções diversas. Com efeito, podemos falar na ética grega apenas de uma maneira mais geral haja vista a existência de diferentes correntes nesse período, mas o que o senso comum entende por ética na antiguidade alimentará uma 
concepção de ética da salvação, que consiste numa releitura da ética grega a partir de um viés teológico. Max Weber (2013) faz uma importante distinção da ética em dois grandes grupos, a saber, a ética da convicção e a ética da responsabilidade. Muito usadas para caracterizar posturas dentro da política, tendo como exemplo o político que tem determinado discurso baseado em suas convicções e que, uma vez no poder, assume um posicionamento diferente em prol da coletividade, a ética da convicção e a ética da responsabilidade podem ser encaradas como conceitos mais gerais, aplicados a todos os homens.

A ética da convicção seria, nesse sentido, aquela que se apoia nos deveres individuais, no cumprimento das obrigações. Já a ética da responsabilidade avalia os fins tendo no horizonte o benefício da coletividade. Em que se pese o fato de que esses extremos não são puros e se contaminam mutuamente, a ética da responsabilidade volta o olhar do homem para além de si, assumindo uma postura altruísta; pensa no bem da maioria baseando-se não apenas nas premissas e convicções pessoais, mas na finalidade e desdobramento de suas ações, deixando que o fim se sobreponha à ideia de dever pré-determinado.

Certamente, a Ética evoca um universo estimulante e cada vez mais necessário de se ter em pauta. Queremos, então, extrair do conceito de ética o necessário para adjetivarmos o humanismo que aqui defendemos. A ética perpassa toda a ação humana, podendo ser considerada nas diferentes culturas, ou no interior de cada atividade laborial. Se jogamos papel na rua ou se praticamos eutanásia, se somos politicamente incorretos ou pessoas insensíveis, nossas ações podem sempre ser avaliadas pelo viés ético. Sabemos o que devemos fazer ou como agir corretamente, mas a liberdade humana nos faz seguir ou não as regras da conduta moral. No entanto, a importante inversão que a ética da responsabilidade promove é a de tirar a centralidade de nossas ações, que residia no eu, para colocá-la no outro. Devo agir eticamente tendo em vista o melhor para o outro, e essa ideia torna-se poderosa se atrelada ao humanismo.

Por um humanismo ético, entendemos um tipo de comportamento humano que não dissocia prática e teoria, que descola o humanismo tradicional da necessidade de erudição ou de escolaridade. O humanismo ético é aquele que prevê a impossibilidade de fazer mal ao outro. É a partir de uma concepção de humanismo ético que podemos conceber o ser humano como um todo, não mais dividido entre aquilo que se prega ou pensa e os atos praticados. A partir dessa concepção, agir eticamente dentro de uma perspectiva humanista pressupõe colocar em prática aquilo que pensamos levando em consideração a integridade de todos os seres humanos, ser altruísta, romper com o egoísmo, no sentido original do termo, cedendo o lugar de centralidade para compartilhá-lo com todos os homens.

Essas considerações acima vão ao encontro do que Edward Said apon- 
ta no livro Humanismo e crítica democrática, sobre como pensamento e prática nem sempre caminham juntos.

\begin{abstract}
Os novos historiadores do humanismo clássico do início da Renascença [...] começaram por fim a examinar as circunstâncias em que figuras icônicas como Petrarca e Boccaccio louvaram o "humano" sem que fizessem um mínimo movimento de oposição ao comércio de escravos mediterrâneo. E, depois de décadas de celebrações dos "pais fundadores" e figuras nacionais heróicas da América, alguma atenção está sendo por fim prestada a suas ligações dúbias com a escravidão, a eliminação dos americanos nativos e a exploração de populações que não eram masculinas, nem proprietárias de terra. (SAID, 2007, p. 69)
\end{abstract}

Consideramos fundamental atrelar o conceito de humanismo ético à superação das distinções entre teoria e prática. Esse humanismo será pleno apenas se abandonarmos o caráter dicotômico dessas instâncias. Pensar e agir de maneira una e coerente é o que nos conduzirá pelo caminho altruísta do humanismo ético. Mesmo se considerarmos contextos históricos e culturais diversos, como é o caso da menção feita por Edward Said, a premissa de que todos somos iguais na diferença é a base para entendermos um humanismo que não esteja enclausurado nas páginas de um livro ou no sistema ético de um pensador, mas que reverbere na prática, nas ações e no mundo.

Quando tomamos o humanismo ético como norte, conseguimos decantar propostas de filósofos que se debruçaram sobre o humanismo, mas navegaram em sentido contrário. O mais notório caso é o de Martin Heidegger. Autor de Cartas sobre o humanismo, Heidegger é constantemente citado por autores que se aproximam desse conceito. Não nos interessa, aqui, discutir a filosofia heideggeriana, e sim destacar como sua biografia nos ajuda a pensar o conceito de humanismo ético pelo seu oposto.

Ao sustentar que toda uma tradição filosófica confundiu o Ser com o Ente, e que o Ser permaneceu esquecido, Heidegger propõe uma ontologia do Ser a partir da sua existência. Isso significa dizer que é a partir da existência humana que Heidegger pensa o Ser, porém, ao fazê-lo, ele se pergunta sobre em que consiste a essência do homem, num procedimento totalizante e que aniquila o outro e se contrapõe a qualquer ideia de alteridade.

\footnotetext{
Para onde se dirige "o cuidado", senão no sentido de reconduzir o homem novamente para a sua essência? Que outra coisa significa isso, a não ser que o homem (homo) se torne humano (humanus)? Deste modo então, contudo, a humanitas permanece no coração de um tal pensar; pois o humanismo é isto; meditar e cuidar para que o homem seja humano e não desumano, inumano, isto é, situado fora da sua essência. Entretanto, em que consiste a humanidade do homem? Ela repousa na sua essência. (HEIDEGGER, 2005, p.17)
}

Quando indagado sobre o uso do conceito humanismo, que deu ori- 
gem ao livro supracitado, Heidegger questiona sua validade.

Você pergunta comment redonner un sens au mot "Humanisme"? Essa questão nasce da intenção de conservar a palavra "Humanismo". Pergunto-me se isto é necessário. Ou será que não se manifesta, ainda, de modo suficiente, a desgraça que expressões desta natureza provocam? Não há dúvida de que há muito se desconfia dos -ismos. Mas o mercado da opinião pública exige constantemente novos. E sempre se está disposto a cobrir esta necessidade. (HEIDEGGER, 2005, p. 11)

A crítica que Heidegger faz no trecho acima é extensiva a outros conceitos, inclusive à Ética. Mas o que afasta seu pensamento do conceito de humanismo que propomos é a própria ideia de essência. Nossa crítica à concepção humanista em Heidegger segue o posicionamento de Emmanuel Lévinas, para quem o pensamento totalizante de Heidegger é motivador da guerra. Lévinas promove uma importante inversão em relação à proposta de Heidegger quando este aponta para o esquecimento do Ser, ao sustentar que a tradição filosófica esqueceu-se, na verdade, do Outro.

Para Lévinas, a ontologia proposta por Heidegger baseia-se em generalizações e violenta o Outro ao não considerar o diferente. Trata-se de uma filosofia do poder e de um pensamento que é motivador da guerra. "A face do ser que se mostra na guerra fixa-se no conceito de totalidade que domina a filosofia ocidental" (LÉVINAS, 2008, p.8). Seria a própria tradição filosófica tributária de atos de violência contra o Outro que testemunhamos através dos séculos?

Para Lévinas, a Ética é a filosofia primeira e o Outro é exterioridade plena. Não se pode capturar ou compreender o Outro, o que está na contramão do pensamento heideggeriano. Nosso interesse ao evocar essa divergência entre dois grandes pensadores do século XX é, sobretudo, sinalizar de que maneira o humanismo ético se manifesta. Ao discorrer sobre a alteridade absoluta, Lévinas denuncia as estratégias de aniquilamento do Outro presentes no pensamento heideggeriano. Esse embate repercutiu nas vidas e nas ações de ambos.

É de se espantar que um filósofo constantemente tomado como referência quando falamos de humanismo tenha sido membro do Partido Nazista. Heidegger se filiou ao Partido Nazista em 1933, ano que marcou a chegada de Hitler ao poder. Em seguida, foi reitor da Universidade de Friburgo, tendo enfrentado a resistência de professores que combatiam o nazismo. Em que se pese a importância de sua obra, que influenciou gerações, as máculas em sua biografia foram reforçadas com a publicação de seus diários, os Cadernos $\mathrm{Ne}$ gros ${ }^{5}$, no qual anotações antissemitas dão o tom da complexidade da situação 6 .

5 Publicados a partir de 2014, os Cadernos Negros (Schwarzen Hefte) esquentam uma antiga discussão acadêmica sobre a obra de Heidegger na medida em que trazem anotações com indisfarçável conotação antissemita.

6 O caso Heidegger consiste na polêmica, intensamente recuperada pela publicação dos Cadernos Negros, da partici- 
No extremo oposto, vale lembrar que Lévinas foi levado a um campo de concentração nazista, no qual permaneceu durante cinco anos, e lá perdeu sua família durante a Segunda Guerra Mundial. Tendo experimentado de forma direta as atrocidades de que o ser humano é capaz, Lévinas passou a se dedicar ao estudo de um pensamento que coloque o Outro no lugar de centralidade. Machado (2008) aponta a importância de seu pensamento.

A originalidade da proposta de Lévinas está na consideração do outro como um mistério, assim como o conceito de rosto como nudez. O outro, para Lévinas, é aquele que tem uma liberdade exterior à minha, que está fora do meu sistema, em que não é possível nenhuma fusão. (MACHADO, 2008, p. 89)

Sendo assim, sustentamos que o humanismo ético se dá na medida em que consideramos tanto nossos pensamentos e teorias quanto nossas práticas e ações. O exemplo de Heidegger e Lévinas não deixa dúvida da importância de se pensar o mundo, mas também de se agir no mundo. Um humanismo ético recusa a filosofia que, de alguma forma, legitima o domínio de um sobre o outro. A alteridade é a chave para mudar o mundo atual, e sem um humanismo que tenha a ética como norte não há transformação possível.

Desde que iniciamos nossa abordagem sobre o humanismo, apontamos para a pluralidade do termo e para definições até mesmo antagônicas que o cercam. Em meio a esse universo de significados, não é de surpreender que o pensamento de um mesmo filósofo seja interpretado de maneira diversa. No caso de Lévinas, é interessante perceber como ele é considerado tanto como humanista quanto como anti-humanista.

É certo que, por vezes, o próprio Lévinas utiliza a expressão anti-humanismo. Porém, fica claro durante a leitura de seus textos que seu trabalho aponta para um humanismo ético, transformador do mundo, e que suas proposições terminam não por aniquilar o humanismo, mas por reinventá-lo. Os pesquisadores que traduziram o livro Humanismo do outro homem apontam para isso, de maneira inequívoca, na orelha da edição brasileira.

Não se trata de rejeitar o humanismo, mas de reativá-lo. As contestações sociopolíticas que marcaram os anos de 1960, na Europa e na França, não trouxeram à luz uma visão satisfatória do mundo e do homem. Urge agora estabelecer uma moral melhor que o humanismo subjetivista,

pação de Heidegger no nazismo. A questão sobre a validade ou não de ler sua obra a partir do comportamento ético do filósofo, fartamente documentado, é das mais instigantes. Porém, esta polêmica foi apenas reavivada a partir da publicação dos referidos diários. Heidegger chegou a ser proibido de lecionar na Alemanha após a Segunda Guerra Mundial em consequência de sua participação ativa no Partido Nazista, tendo chegado a referendar, em 1933, um decreto que bania não arianos do serviço público. Longe de esgotar-se, a polêmica reverbera na obra de Peter Trawny, que editou os Cadernos Negros e escreveu os livros Heidegger e o mito da conspiração judaica mundial e La Liberté d'Erreur avec Heidegger, e em inúmeros outros autores que se dividem entre a defesa do banimento de Heidegger à contextualização e separação entre a obra e seu posicionamento ético. 
uma moral capaz de proteger o homem contra o próprio homem.

Quem fracassou não foi o humanismo, mas sim as interpretações que dele foram feitas. Esse humanismo, reduzido a esquemas simplistas e rígidos, esqueceu os valores soberanos que abrigava em seu seio. Nestas páginas, Lévinas pede que se compreenda de outro modo a mensagem humanista, desenvolvendo-a e afinando-a sempre mais. (PIVATTO, 1993, [orelha do livro])

Na contramão dessa abordagem, Lévinas é também associado à pauta anti-humanista. $O$ reducionismo com que o conceito humanismo é por vezes tratado justifica a confusão. Afinal, o que seria o anti-humanismo se não existe nem mesmo consenso sobre o que seja humanismo? Hutchens (2007) aponta que Lévinas se afasta tanto de Sartre quanto de Heidegger e, ao fazê-lo, ataca o humanismo. Porém, a perspectiva de Lévinas não é a de negar o humanismo como um todo, mas certos tipos de humanismo, alguns elencados aqui anteriormente. Sua crítica está dirigida, na verdade, à centralidade do eu, que marca a história do pensamento ocidental.

Curiosamente para um pensador tão religioso, Lévinas é um humanista relutante que defende o anti-humanismo contra o humanismo apesar de ser contra seus excessos radicais. $O$ anti-humanismo ataca a arrogância do eu-humanista, sendo mais modesto em sua avaliação dos poderes do eu, está aberto à interpretação ética. (HUTCHENS, 2007, p. 176)

Mesmo considerando as dificuldades no manuseio desses conceitos, o grau de reducionismo chega, por vezes, a invalidar qualquer abordagem mais objetiva, ora referindo-se ao autor como humanista, ora como anti-humanista. Hutchens insiste: "não há qualquer dúvida de que ele é um humanista alternativo [...]. E é isso que o leva a aprovar o anti-humanismo [...] que, é preciso dizer, abre um espaço para a religião verdadeira" (p.176). Sabemos que é difícil entender o termo humanismo em toda a sua complexidade, mas tal imprecisão entre humanismo e não-humanismo só tende a tornar a questão mais confusa, sobretudo quando a ela se atrela expressões como religião verdadeira, como se fosse possível aferir tal condição de verdade a uma religião em detrimento de outras ou no interior de uma mesma religião, o que funciona como um farol da desatenção com que o humanismo é frequentemente abordado.

Entendemos que o pensamento de Lévinas se enquadra (e inspira) o humanismo ético que propomos e sabemos que quando ele se refere ao humanismo criticamente, ele o faz para reativar o conceito em sua essência, ou talvez para dotá-lo de algo que até então lhe faltava. Seu livro Humanismo de outro homem não deixa nenhuma dúvida quanto a isso. O que Lévinas propõe é, sim, um humanismo ético, pois relacional, dependente do Outro que assume, em seu pensamento, o lugar de protagonismo.

O desafio parece ser o de fazer valer o pensamento de Lévinas de maneira 
plena. Como superar o legado de uma tradição filosófica bimilenar que coloca o Eu no lugar central e tomar as proposições levinasianas em sua plenitude?

Desejo do outro como necessidade daquele que não tem mais necessidades, que se reconhece na necessidade de um Outro que é Outrem, que não é nem meu inimigo (como em Hobbes e Hegel), nem meu "complemento", como o é ainda na República de Platão, que é constituída porque faltaria alguma coisa à subsistência de cada indivíduo. (LÉVINAS, 1993, p. 48-49)

Ao colocar o Outro no lugar central, Lévinas desafia a formação do nosso pensamento, invertendo as convicções e comportamentos do eu-sujeito. Não seria essa lógica, a do Eu no lugar central, que de alguma forma fundamenta, através dos séculos, boa parte das agruras que atravessaram a humanidade? O que subjaz aos interesses geopolíticos e econômicos de uma guerra se não a ideia de dominação do Outro? Do ciúme mais corriqueiro aos crimes passionais, muitos deles legitimados pela sociedade durante tanto tempo sob a argumentação de defesa da honra, não estamos sempre atravessados pela ideia de dominação de Outrem, o Outro sempre como complementação do Eu ou como meu inimigo? E o que falar das religiões em seus processos de angariar seguidores, de transformar o Outro em Eu através de um ideário religioso e da existência de um Deus que nos converta, literalmente, no mesmo? O humanismo ético está, necessariamente, na centralidade do Outro.

O questionamento de si é precisamente o acolhimento do absolutamente outro. A epifania do absolutamente outro é rosto em que o Outro me interpela e me significa uma ordem, por sua nudez, por sua indigência. Sua presença é uma intimação para responder. O Eu (Moi) não toma apenas consciência dessa necessidade de responder, como se se tratasse de uma obrigação ou de um dever particular sobre o qual ele teria que decidir. (LÉVINAS, 1993, p. 53)

Apesar da adoção esporádica do termo anti-humanismo e da constante e sólida crítica ao humanismo tradicional, é o próprio Lévinas quem aponta que a superação do humanismo não passa de um modismo. Só resta resgatá-lo, transformando-o em humanismo ético, dotando-o daquilo que lhe faltava e sem o que o próprio humanismo se perde.

Fim do humanismo, fim da metafísica - morte do homem, morte de Deus (ou morte a Deus!) -, ideias apocalípticas ou slogans da alta sociedade intelectual. Como todas as manifestações do gosto - e dos maus gostos - parisienses, estas proposições se impõem com a tirania da última moda, mas se colocam ao alcance de todos os bolsos e se degradam. (LÉVINAS, 1993, p. 93)

O humanismo ocidental, afirma o autor, apoia-se na ambiguidade das belas palavras e ignora o real de violências e de exploração (1993, p.92). A filo- 
sofia de Lévinas quer mudar a ordem das coisas, e aponta a juventude como estratégia para a aproximação do Outro, que se afasta das belas palavras, da erudição, para mostrar a humanidade do homem.

Esta crítica rejeita a responsabilidade coagulada em "belas palavras", e onde o Dizer, reduzido ao Dito, entra em conjunção com suas próprias condições, faz estrutura com seus contextos e perde sua juventude do dizer; juventude que é ruptura do contexto, palavra que decide, palavra nietzschiana, palavra profética, sem estatuto do ser, mas sem arbitrariedade, pois brotada da sinceridade, quer dizer, da própria responsabilidade pelo outro. (LÉVINAS, 1993, p. 107-108)

É nesse sentido que atrelamos o humanismo ético a uma concepção contra-hegemônica dos direitos humanos. Na verdade, os direitos humanos têm uma tendência propositiva desde suas origens, haja vista os inúmeros tratados, conferências, congressos etc., que buscam estabelecer e positivar direitos, a partir da Declaração Universal dos Direitos Humanos, de 1948. Contudo, de alguns anos para cá, notadamente a partir da Conferência de Viena, de 1993, que estabeleceu como fundamentos dos direitos humanos a universalidade, a interdependência e a indivisibilidade, alguns estudos deram conta de problematizar a questão da universalidade, apontando o caráter discursivo hegemônico desse fundamento, que está no próprio cerne de uma declaração universal.

Slavoj Zizek (2010) escreve um duro texto em que ataca essa concepção hegemônica dos direitos humanos, afirmando que estes servem como um braço do neoimperialismo e como uma forma de dominação entre os ditos países centrais sobre os países periféricos. Nesse texto, intitulado Contra os direitos humanos, o autor ataca frontalmente os direitos humanos universais, que não seriam nada além dos direitos dos homens brancos proprietários, exploradores de mulheres e homens no exercício de dominação política e em nome dos interesses do mercado. $\mathrm{O}$ enfrentamento dos direitos humanos se dá justamente pelo ataque ao princípio da universalidade: “Em que condições os indivíduos se experimentam a si mesmos enquanto sujeitos de direitos humanos universais?" (p. 26).

Em outra perspectiva, Boaventura de Sousa Santos (2014) discorre sobre os discursos hegemônicos e contra-hegemônicos dos direitos humanos. A constatação de que o próprio princípio da universalidade precisa ser colocado em xeque é central para que o autor afirme a importância da valorização do regional pela sua singularidade: "O seu caráter único e específico pode ser uma força tão poderosa quanto a universalidade e generalidade do universal" (2014, p. 39).

Porém, a crítica feita por Santos é propositiva no sentido de uma mudança na acepção dos direitos humanos. Isso porque são inúmeras as conquistas em decorrência da luta por positivação de direitos em âmbito internacional. Portanto, consciente de uma narrativa hegemônica dos direitos 
humanos fundamentada no patriarcado, no colonialismo, o autor propõe uma concepção contra-hegemônica que valorize o fundacional ao mesmo tempo em que se mantenha enquanto luta mundial.

As críticas acima dão conta de sinalizar que os direitos humanos são um campo em construção, e adentram o mesmo terreno polissêmico que marcou a história do humanismo. Assim, a necessidade de adjetivação se torna premente, tanto no caso de um humanismo ético, quanto dos direitos humanos contra-hegemônicos. Seja como for, o que nos interessa é vincular os direitos humanos a uma perspectiva humanista que exclui uma gama de sentidos sobre os quais discorremos. A ética, enquanto fenômeno relacional, se torna central para pensarmos na responsabilidade pelo outro e na luta pela positivação de direitos.

Humanismo e direitos humanos encontram-se, portanto, dentro de certo sentido que cada um desses conceitos possui, um sentido que aponta para a transformação da realidade a partir da reflexão e da ação, da valorização da diversidade, do equacionamento entre universalidade e regionalismos, na construção de sujeitos de direitos amparados pela fundamentação teórica do humanismo ético que, mesmo silenciosamente, alimenta e atravessa os direitos humanos

\section{Considerações finais}

Os múltiplos sentidos de humanismo tornaram este um conceito de difícil manuseio. A largura polissêmica de um conceito não é algo necessariamente ruim, e é mesmo comum que, ao longo do tempo, o caminho seja o dos variados sentidos que as palavras vão assumindo. Porém, no caso do humanismo, a polaridade que certos sentidos assumem acaba por anuviar as possibilidades de sua aplicação.

Como buscamos demonstrar através deste trabalho, o humanismo acumula acepções não só distintas, mas radicalmente opostas. Quando falamos no estudo de humanidades, aproximando-nos do sentido de erudição, estamos na contramão de uma utilização da expressão que, através da ética como relacional, pense em termos levinasianos da responsabilidade pelo outro e, sobretudo, tenha uma dimensão prática de transformação do mundo.

Os direitos humanos, em sua translação contra-hegemônica, com sua pulsão pela positivação de direitos e pela valorização das diferenças e da diversidade, são atravessados por um humanismo ético que está profundamente conectado com o desejo de mudança e de responsabilidade pelo outro, numa perspectiva levinaseana. Aproximar esses conceitos implica na necessidade de adjetivá-los para que possamos significá-los de maneira clara, o que também passa pela negação de uma série de sentidos que foram dados a ambos e que os distanciariam definitivamente. 
A contemporaneidade é marcada pelos direitos humanos, e ainda que pouco se fale em humanismo nos tempos atuais, sobretudo quando pensamos no contexto dos direitos humanos, há uma interdependência entre eles. Até que ponto a formulação dos direitos humanos só foi possível pelo lastro deixado pelo humanismo ético? Tal humanismo se fez presente sempre que mulheres e homens, nas mais diversas regiões do planeta, levantaram-se contra sistemas opressores e lutaram por direitos e pela garantia da dignidade da pessoa humana. Assim, refletimos sobre o conceito de humanismo para consolidarmos a noção de humanismo ético e, a partir desta, chegarmos aos direitos humanos como atravessados por uma dimensão humanista que continua a constituir-se como caminho de luta e de construção de um novo porvir.

\section{Referências}

ARISTÓTELES. Ética a Nicômaco; Poética. (Os Pensadores, v. 2) São Paulo: Nova Cultural, 1991.

BRANDALISE, Carla. Magnum miraculum est homo: origens históricas do humanismo renascentista italiano. In: ORO, Ari Pedro (org.). Representações sociais e humanismo latino no Brasil atual. Porto Alegre: Editora da UFRGS, 2004.

FROMM, Eric. Conceito marxista do homem. Zahar, Rio de Janeiro, 1983.

HEIDEGGER, Martin. Carta sobre o humanismo. São Paulo: Centauro, 2005.

HUTCHENS, B. C. Compreender Lévinas. Petrópolis: Vozes, 2007.

LÉVINAS, Emmanuel. Humanismo do outro homem. Petrópolis: Vozes, 1993.

LÉVINAS, Emmanuel. Totalidade e infinito. Lisboa: Edições 70, 2008.

MARCONDES, Danilo. Iniciação à história da filosofia: dos pré-socráticos a Wittgenstein. Rio de Janeiro: Zahar, 2002.

MACHADO, Eliany Salvatierra. Pelos caminhos de Alice: vivências na educomunicaçao e a dialogicidade no Educom. Tese de doutorado. São Paulo, USP, 2008.

NAVILLE, Pierre. Discussão. In: SARTRE, Jean-Paul. O existencialismo é um humanismo. Petrópolis, Rio de Janeiro: Vozes, 2014. 
NOGARE, Pedro Dalle. Humanismos e anti-humanismos. Petrópolis: Vozes, 1981.

NOVAES, Adauto (org.). Ética. São Paulo: Companhia das Letras; Secretaria Municipal de Cultura, 2002.

PEGORARO, Olinto. Introdução à ética contemporânea. Rio de Janeiro: UAPÊ, 2005.

PESSANHA, José Américo Motta. As delícias do jardim. In: NOVAES, Adauto (org.). Ética. São Paulo: Companhia das Letras; Secretaria Municipal de Cultura, 2002.

PIVATTO, Pergentino (coord.) [orelha do livro] In: LÉVINAS, Emmanuel. Humanismo do outro homem. Petrópolis: Vozes, 1993.

SAID, Edward. Humanismo e crítica democrática. São Paulo: Cia. das Letras, 2007.

SANTAELLA, Lúcia. Pós-humano, pós-humanismo e anti-humanismo: discriminações. In: FELICE, Mássimo Di; PIERDDU, Mário. Pós-humanismo: as relações entre o humano e a técnica na época das redes. São Caetano do Sul, SP: Difusão Editora, 2010.

SANTOS, Boaventura de Sousa. Direitos humanos, democracia e desenvolvimento. In: CHAUÍ, Marilena; SANTOS, B. de Sousa. Direitos humanos, democracia e desenvolvimento. São Paulo: Cortez, 2014.

SANTOS, Boaventura de Sousa; MARTINS, Bruno Sena. O pluriverso dos direitos humanos: a diversidade das lutas pela dignidade. Belo Horizonte: Autêntica, 2019.

SANTOS, Jessy. Filosofia e humanismo. São Paulo: Duas cidades / Secretaria de Estado de Cultura, 1981.

SARTRE, Jean-Paul. O existencialismo é um humanismo. Petrópolis, Rio de Janeiro: Vozes, 2014.

WEBER, Max. Ciência e política: Duas Vocações. São Paulo: Cultrix, 2013.

Recebido em: 2 de fevereiro de 2021.

Aprovado em: 22 de fevereiro de 2021. 
